\title{
THERMODYNAMICS ANALYSES ON REGENERATIVE STEAM CYCLE WITH TWO TANKS FOR HTGR-10 CONCEPT
}

\section{ANALISIS TERMODINAMIKA SIKLUS UAP REGENERATIF DENGAN DUA TANGKI UNTUK KONSEP HTGR-10}

\author{
Sri Sudadiyo, Geni Rina Sunaryo \\ Center for Nuclear Reactor Technology and Safety - BATAN \\ Puspiptek Area Building 80, Tangerang 15310 \\ e-mail address: sudadiyo@batan.go.id
}

Received 13 March 2017, received in revised form 9 May 2017, accepted 15 August 2017

\begin{abstract}
THERMODYNAMICS ANALYSES ON REGENERATIVE STEAM CYCLE WITH TWO TANKS FOR HTGR10 CONCEPT. In this work, steam cycle from a nuclear power plant is explored in order to increase electric power efficiency and output. A thermal source in the form of a HTGR-10 concept is considered. The power conversion unit of HTGR-10 consists of steam generators, turbines, condensers, pumps, and connecting pipes. Helium is used as the core coolant and the working fluid for power conversion unit is water/steam. The proposed thermodynamic process modification has been evaluated for regenerative steam power cycle of this reactor. The scope of study covered regenerative steam cycle with two tanks including feed water tank and intermediate feed water tank. The evaluation analyzes the effect of pressure, efficiencies of turbine and pumps, and tanks against thermal efficiency. The Cycle-Tempo software is used to simulate and optimize those effects on steam cycle based on HTGR-10. The results indicate improvements of as much as $2.65 \%$ in thermal efficiency and $0.271 \mathrm{MW}$ in electric power.
\end{abstract}

Keywords: Regenerative cycle, steam turbine, HTGR-10 concept

\section{ABSTRAK}

ANALISIS TERMODINAMIKA SIKLUS UAP REGENERATIF DENGAN DUA TANGKI UNTUK KONSEP HTGR-10. Dalam penelitian ini, siklus uap dari pembangkit tenaga nuklir diteliti untuk meningkatkan efisiensi dan keluaran daya listrik. Sumber termal dalam bentuk konsep HTGR-10 dipertimbangkan. Unit konversi daya dari HTGR-10 terdiri dari penghasil uap, turbin, kondensor, pompa, dan pipa penghubung. Helium digunakan sebagai pendingin teras dan fluida kerja untuk unit konversi daya adalah air/uap. Modifikasi proses termodinamika yang diusulkan telah dievaluasi untuk siklus tenaga uap regeneratif dari reaktor ini. Cakupan penelitian meliputi siklus uap regeneratif dengan dua tangki termasuk tangki air umpan dan tangki air umpan antara. Evaluasi menganalisis pengaruh dari tekanan, efisiensi turbin dan pompa, dan tangki terhadap efisiensi termal. Perangkat lunak Cycle-Tempo digunakan untuk mensimulasikan dan mengoptimasikan pengaruh ini pada siklus uap berbasis HTGR-10. Hasil menunjukkan perbaikan sebesar 2,65\% dalam efisiensi termal dan 0,271 MWe dalam daya listrik.

Kata kunci: Siklus regeneratif, turbin uap, konsep HTGR-10

\section{INTRODUCTION}

In the nuclear power plants, steam cycle will eject further heat to the environment than its converting to useful energy. The useful energy of the steam cycle can be defined as multiplication between thermal power and efficiency. The heat which is given to the environment named thermal pollution. The thermal efficiency of the power plant is ratio of useful energy against given heat energy [1]. Therefore, the amount of thermal energy is discharged as pollution per unit quantity of useful energy is given by one minus thermal efficiency per thermal efficiency [2]. From this statement it is evident that increasing the thermal efficiency value of the steam cycle of the nuclear power plant reduces the ratio of the thermal pollution to useful energy output [1,2]. Increasing the thermal efficiency will reduces thermal pollution, amount of nuclear fuel, and the cost of power production.

This paper studies the concept of an experimental nuclear power reactor (HTGR-10) as the nuclear power plant model in Indonesia. HTGR-10 concept is high temperature gas-cooled reactor that uses helium within primary cooling system and water/steam in the secondary cooling system. The steam cycle of HTGR-10 employs 
Jurnal Iptek Nuklir Ganendra

Ganendra Journal of Nuclear Science and Technology

Vol. 20, No. 2, Juli $2017: 73-81$

the basic Rankine cycle. The isentropic compression process passes through the feed water pump, the isobaric heat addition process occurs inside steam generator, the isentropic expansion process is developed within the turbine, and the isobaric heat rejection process takes place in the condenser.

This study proposes the regenerative steam cycle for HTGR-10 with thermal power of $10 \mathrm{MW}_{\text {th. }}$. The thermal efficiency value of the basic steam cycle (Rankine cycle) can be improved by heating the two tanks with internal heat before water enters to the steam generator. In the regenerative steam power cycle, steam is streamed from extraction pressure channel in the turbine and is used to heat the feed water. The two tanks used are feed water tank and intermediate feed water tank. The superheated steam is generated at high pressure inside the steam generator and supplied to the steam turbine in which it expands adiabatically from high pressure to extraction pressure. A fraction of the total flow rate of steam is extracted and sent to the feed water tank and the intermediate tank. In these tanks, the extraction steam is mixed directly with feed water emanating from condensate pump. The condensing steam heats the water until it is at the saturation temperature at lowest pressure of the cycle. The saturated condensate and feed water are pumped to the steam generator pressure.

The objective of paper is to analyze the effect of inlet pressures, extraction pressure, turbine efficiency, pumps efficiencies, and tanks on thermal efficiency value include feed water tank and intermediate feed water tank of the regenerative steam cycle for HTGR-10 concept. The solution method is created scenario of the cases for obtaining the enthalpy values of each observation points from steam cycle. The Cycle-Tempo is needed to simulate the entire component models of the regenerative steam cycle. Thermal efficiency of regenerative steam cycle is calculated to get the performance value [3].

\section{METHODOLOGY}

Basic steam cycles are typically used for gas-cooled reactor with its major components is depicted in Figure 1 along with the thermodynamics states of the working fluid [4]. This steam cycle is composed by a steam generator, a condenser, a pump, and a turbine. From state 1 to state 2, an ideal pump executes an adiabatic, reversible (isentropic) process to raise the water from the pressure of saturated liquid to the pressure of steam generator $[5,6,7]$. From state 2 to state 3 , a steam generator heats the water liquid at a constant pressure (isobar transformation) moving from a saturated liquid state 2' to a saturated vapor state $3^{\prime}$ in which all the liquid becomes steam. Then the steam is superheated until it reaches the state 3 . After, the superheated steam enters in a turbine where it produces an expansion through and adiabatic, reversible process. The superheat process is necessary in order to guarantee that within turbine only steam is present, this preserving the turbine blades from condensation and erosion [8,9]. However, the amount of superheat should be kept as lower as possible in order to avoid waste of energy and maximize the thermal efficiency performance of entire cycle.
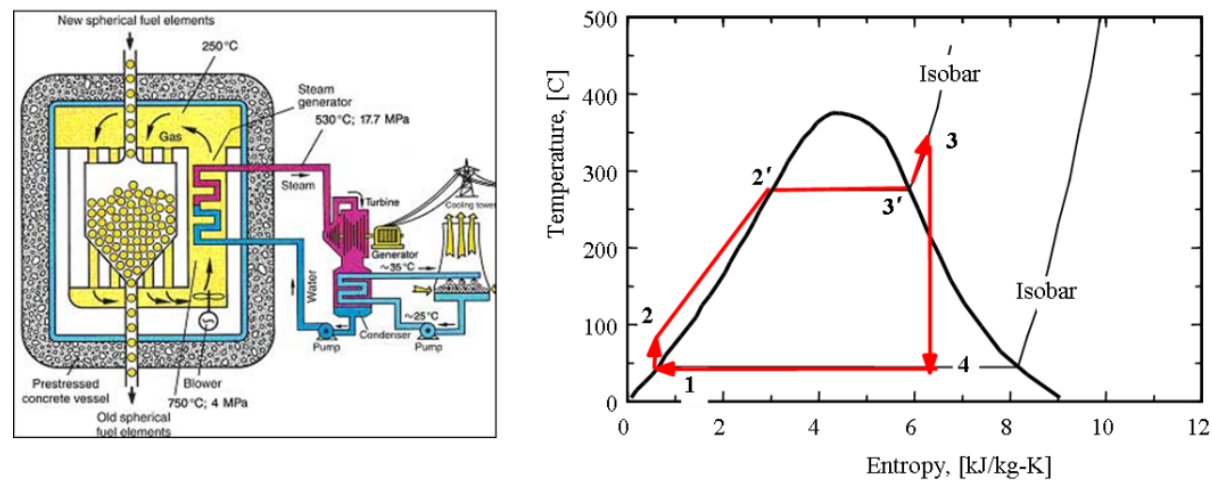

Figure 1. Basic steam cycle configuration within nuclear power plant [4]

The mechanical friction that occurs when steam passes over the blades of the turbine generates thermal energy which increases the enthalpy and reduces the net work ouput of the outgoing steam. Thus, the enthalpy of steam after expansion is higher than which it would be at the end of isentropic expansion. Turbine efficiency $\left(\eta_{t}\right)$ of the steam power cycle can be written as followed [4]: 


$$
\eta_{T}=\frac{h-h_{i}}{h-h_{i s}}
$$

where $h$ is turbine inlet enthalpy, $h_{i}$ is extraction enthalpy, and $h_{i s}$ is extraction enthalpy on isentropic expansion. By using the first law of thermodynamics and by assuming that change of kinetic and potential energy is negligible, the enthalpy increase of the condensate across an ideal feed water pump is [4]

$$
\Delta h=\frac{v \Delta P}{\eta_{P}}
$$

where $\Delta p$ is the difference of pressure across the feedwater pump, $v$ is the specific volume of water. As seen on the Equation (2), if the pump efficicency $\left(\eta_{p}\right)$ is less than $100 \%$, the increasing enthalpy is greater than that given in the previous equation because some of mechanical work supplied to the pump is converted to thermal energy.

By making an energy balance for feed water tank, the amount of steam extracted from turbine can be calculated. Total energy enter to tank equals with total energy leaving tank. The specific energy output of the turbine is total specific energy drop of steam generator and can be determined as followed $[4,5]$ :

$$
\dot{W}_{T}=\dot{m} \Delta h_{T}
$$

The energy required to power the pumps can be determined as follows $[4,5]$ :

$$
\dot{W}_{P}=\dot{m} \Delta h_{P}
$$

The pump works are negative, which means that the work must be supplied to each pump from an external source. The total specific heat transfer in the steam generator is total heat transfer required to generate the superheated steam from feedwater and can be found from $[4,5]$ :

$$
\dot{Q}=\dot{m} c_{P} \Delta T
$$

The thermal efficiency of steam cycle is ratio of total useful energy output to the total energy added in the HTGR10 core, as followed $[4,6]$ :

$$
\eta_{t h}=\frac{\dot{W}_{T}-\sum \dot{W}_{P}}{\dot{Q}}
$$

By applying for the above equations and by using properties values obtained from the Mollier diagram and steam tables, the Cycle-Tempo package will calculate the thermal efficiency for different inlet steam pressures, different turbine and pumps efficiencies, and for different values of extraction pressures.

The proposed regenerative steam cycle to be utilized for HTGR-10 which is planned to be build in Puspiptek area, Serpong, as can be seen in Figure 2. The regenerative steam cycle has been reviewed and analyzed by using Cycle-Tempo Software. Cycle-Tempo is a computer program for thermodynamic modeling and optimization of systems for the production of electricity. Therefore, this computer code can be used to calculate the relevant mass and energy flows in the system of HTGR-10. This computer code package program was developed by TU Delft [10]. The description about the regenerative steam cycle for HTGR-10 is as followed: the initial working fluid of helium gas as coolant of HTGR-10 core comes out from the circulator with mass fraction $100 \%$. The helium is then streamed to the core, and in the steam generator the helium is cooled by the working fluid of water that comes out from the regenerator. After flowing through the feedwater heater the hot water enters into steam generator. In the steam generator the hot water is heated again until reaching superheated vapor condition. Then, the mass flow of superheated steam containing $100 \%$ vapor phase goes to the turbine for producing the mechanical power. The steam that comes out from the turbine is utilized further as a heating fluid in the tanks which has a rich liquid phase coming out from condenser. The process is repeated as a cycle. 
Jurnal Iptek Nuklir Ganendra

Ganendra Journal of Nuclear Science and Technology

Vol. 20, No. 2, Juli 2017 : 73-81

Figure 2 shows the schematic diagram of the proposed regenerative steam cycle to be used to the HTGR10 with thermal power of $10 \mathrm{MW}_{\text {th }}$ in Serpong, which employs water/steam as a working fluid. For the purpose of calculations the following assumptions are made: (a) the system is in steady state, (b) the pressure drop in steam or water pipes is negligible. (c) the conduction, convection, and radiation losses from the system are negligible. (d) turbine efficiency is constant regardless of the amounts of extraction ports. (e) the pressure drop within the feedwater tank is negligible. $(\mathrm{f})$ water leaving the tanks (including feedwater tank and intermediate feedwater tank) and condenser is in the saturated water at the respective pressures. (g) steam leakage is negligible. (h) condenser pressure is $0.008 \mathrm{MPa}$. (i) steam temperature of turbine inlet is constant at $435^{\circ} \mathrm{C}$.

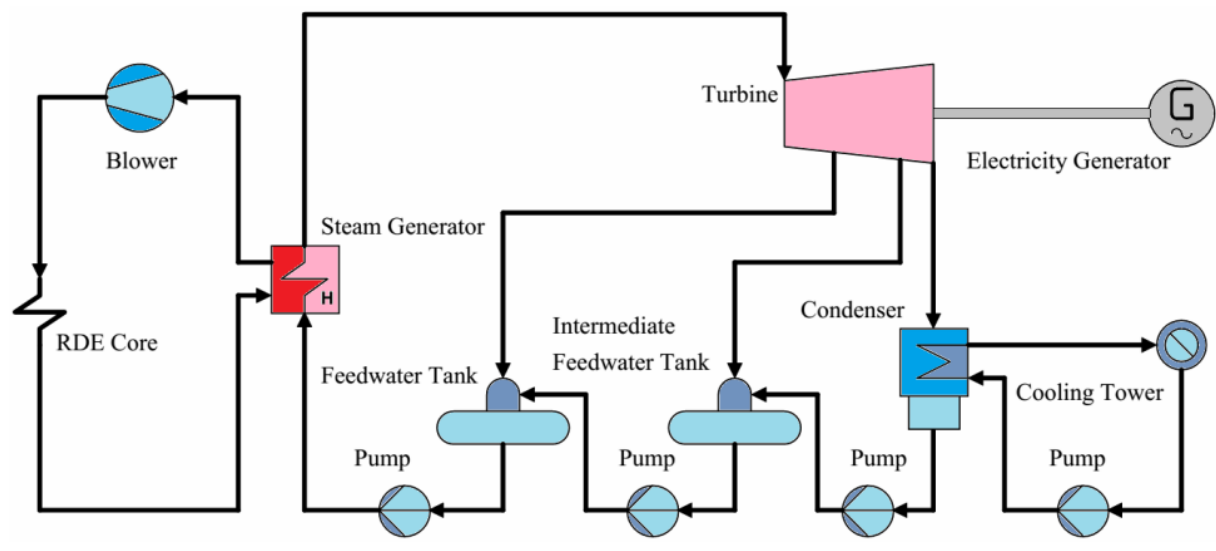

Figure 2. Proposed design of regenerative steam cycle for HTGR-10 with thermal power of $10 \mathrm{MW}$ th

\section{RESULTS AND DISCUSSIONS}

Table 1 is the calculation results of thermodynamic data for HTGR-10 concept by using the Cycle-Tempo software. The thermodynamic conditions of the HTGR-10 core are pressure of 30 bars, inlet temperature of 250 ${ }^{\circ} \mathrm{C}$, outlet temperature of $700{ }^{\circ} \mathrm{C}$, and helium mass flowrate of $4.279 \mathrm{~kg} / \mathrm{s}$. For case of basic steam cycle without feed water tank, it is observed that electricity value of $2.804 \mathrm{MW}$, steam mass flowrate of $3.231 \mathrm{~kg} / \mathrm{s}$, and thermal efficiency of $26.446 \%$. For case of regenerative steam cycle with one feed water tank, it can be seen that electricity value of $2.998 \mathrm{MW}$, steam mass flowrate of $3.144 \mathrm{~kg} / \mathrm{s}$ with quality of $88.32 \%$ entering to condenser, and thermal efficiency of $28.347 \%$.

Table 1. Thermodynamic data of steam turbine cycle for HTGR-10 concept.

\begin{tabular}{lll}
\hline Observed Parameter & Basic Cycle & Regenerative Cycle \\
\hline Amounts of feed water tank & - & 1 \\
Electricity power, $\mathrm{MW}$ e & 2.804 & 2.998 \\
Core pressure, $\mathrm{MPa}$ & 3 & 3 \\
Core inlet temperature, ${ }^{\circ} \mathrm{C}$ & 250 & 250 \\
Core outlet temperature, ${ }^{\circ} \mathrm{C}$ & 700 & 700 \\
Mass flowrate of helium, $\mathrm{kg} / \mathrm{s}$ & 4.279 & 4.279 \\
Turbine inlet pressure, $\mathrm{MPa}^{\mathrm{M}}$ & 3.5 & 3.5 \\
Turbine inlet temperature, $^{\circ} \mathrm{C}$ & 435 & 435 \\
Mass flowrate of steam, $\mathrm{kg} / \mathrm{s}$ & 3.231 & 3.77 \\
Steam quality, $\%$ & 88.75 & 88.32 \\
Feed water tank pressure, MPa & - & 0.4422 \\
Condenser pressure, $\mathrm{MPa}$ & 0.008 & 0.008 \\
Cooling water, liter/s & 235.804 & 228.304 \\
Thermal efficiency, $\%$ & 26.446 & 28.347 \\
\hline
\end{tabular}

The properties values can be obtained from software package of the Cycle-Tempo for the steam and used in calculating the efficiency of steam cycle for all sets of tanks at the condenser pressure of 0.08 bars. Figure 3 
depics HTGR-10 concept with regenerative steam cycle with two tanks including feed water tank and intermediate feed water tank by using Cycle-Tempo. Specific volume of water of $0.001 \mathrm{~m}^{3} / \mathrm{kg}$, and the enthalpy of water of $173.85 \mathrm{~kJ} / \mathrm{kg}$. The electricity power of HTGR-10 was about $3.075 \mathrm{MW}$. The internal turbine efficiency is enthalpy drop ratio of the actual process to the isentropic process for the same pressure conditions, as shown in the Equations (1) and (2). Internal turbine efficiency includes the effects of all losses due to friction in the turbine such as nozzles, blades, and so forth. It is also includes moisture losses due to the wet steam at the blade entry. Table 2 shows the enthalpy and entropy values for regenerative steam turbine cycle with two feed water tanks at the process diagram. The turbine inlet temperature is $435^{\circ} \mathrm{C}$ and turbine inlet pressure 35 bars. The friction that occurs when steam passes over the turbine blades generates the thermal energy which increases the enthalpy and reduces the net work output of the outgoing steam. As seen in the Table 2, the enthalpy of steam after the expansion process is higher than which it would be at the end of isentropic expansion. Thermodynamic analysis had carried out to two extraction points of turbine for the two tanks. The specific energy output of the turbine can be calculated by using Equation (3) for yielding its efficiency.

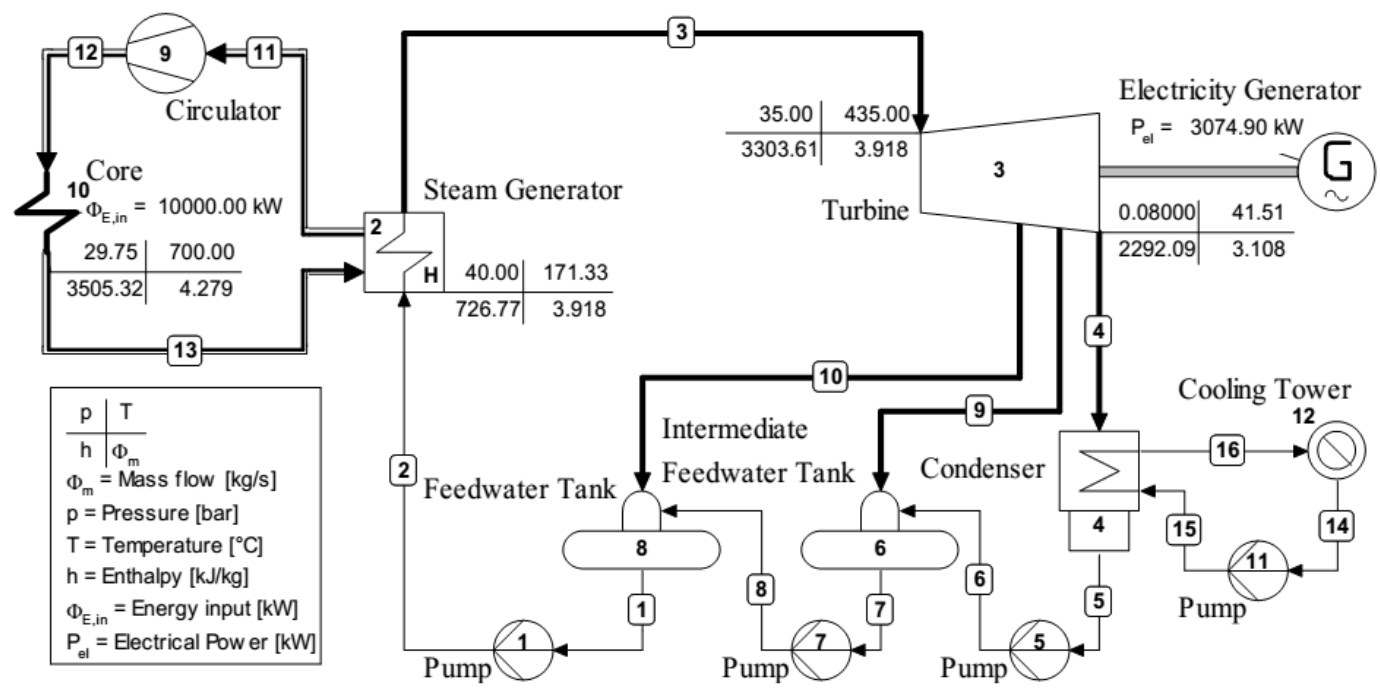

Figure 3. Cycle-Tempo simulation on regenerative steam turbine with two tanks for HTGR-10

Table 2. Thermodynamic data of regenerative steam cycle with two feed water tanks for HTGR-10.

\begin{tabular}{llllll}
\hline Pipe No. & $\begin{array}{l}\text { Pressure } \\
{[\mathrm{MPa}]}\end{array}$ & Temperature $\left[{ }^{\circ} \mathrm{C}\right]$ & Mass Flow $[\mathrm{kg} / \mathrm{s}]$ & Enthalpy $[\mathrm{kJ} / \mathrm{kg}]$ & Entropy $[\mathrm{kJ} / \mathrm{kg} . \mathrm{K}]$ \\
\hline 1 & 0.8044 & 170.64 & 3.918 & 722.02 & 2.0482 \\
2 & 4 & 171.33 & 3.918 & 726.77 & 2.0509 \\
3 & 3.5 & 435 & 3.918 & 3303.61 & 6.9592 \\
4 & 0.008 & 41.51 & 3.108 & 2292.09 & 7.3244 \\
5 & 0.008 & 41.51 & 3.108 & 173.85 & 0.5925 \\
6 & 0.1166 & 41.52 & 3.108 & 174 & 0.5926 \\
7 & 0.1166 & 103.96 & 3.477 & 435.81 & 1.3515 \\
8 & 0.8044 & 104.07 & 3.477 & 436.77 & 1.3522 \\
9 & 0.1166 & 103.96 & 0.369 & 2640.8 & 7.1986 \\
10 & 0.8044 & 260.19 & 0.441 & 2972.28 & 7.0789 \\
11 & 2.954 & 245.71 & 4.279 & 1146.16 & 27.3609 \\
12 & 3 & 250 & 4.279 & 1168.44 & 27.3716 \\
13 & 2.975 & 700 & 4.279 & 3505.32 & 30.6121 \\
14 & 0.101 & 15 & 225.327 & 63.08 & 0.2245 \\
15 & 0.2 & 15.01 & 225.327 & 63.21 & 0.2246 \\
16 & 0.111 & 22.01 & 225.327 & 92.43 & 0.3251 \\
\hline
\end{tabular}


Jurnal Iptek Nuklir Ganendra

Ganendra Journal of Nuclear Science and Technology

Vol. 20, No. 2, Juli 2017 : 73-81

By using the Equations (3), (4), (5), and (6), the thermal efficiency is calculated for regenerative steam cycle with two open feed water tanks. The variables of steam cycle are different inlet steam pressure, extraction pressures, turbine efficiency, and pump efficiency. These variables were entered to the Cycle-Tempo package and the results of thermal efficiency were plotted on the graphs. Figure 4 describes that the maximum thermal efficiency of the regenerative steam cycle with two tanks occurs at optimum pressure of feed water tank of 0.8734 $\mathrm{MPa}$. The maximum thermal efficiency reached is $29.096 \%$ with the steam generator pressure of $4 \mathrm{MPa}$. The thermal efficiency will decrease by decreasing the steam generator pressure. Figure 5 shows the calculation results for the thermal efficiency at the fixed extraction pressure of intermediate feed water tank of $0.1454 \mathrm{MPa}$. The optimum thermal efficiency of the regenerative steam cycle occurs at extraction pressure of turbine between $0.3 \mathrm{MPa}$ and $1.3 \mathrm{MPa}$ for any inlet pressure of feed water tank. The thermal efficiency decreases by increasing the pressure of feed water tank (higher than $1.3 \mathrm{MPa}$ ). For figures 4 and 5 , the thermal efficiency of this steam cycle was obtained from thermodynamic conditions as follows: turbine inlet temperature of $435{ }^{\circ} \mathrm{C}$, turbine efficiency of $89.8 \%$, and pumps efficiencies of $75 \%$. This optimum extraction pressure was not markedly changed by different values of turbine efficiency and pump efficiencies, and steam generator pressure was varied from $3 \mathrm{MPa}$ to $4 \mathrm{MPa}$.

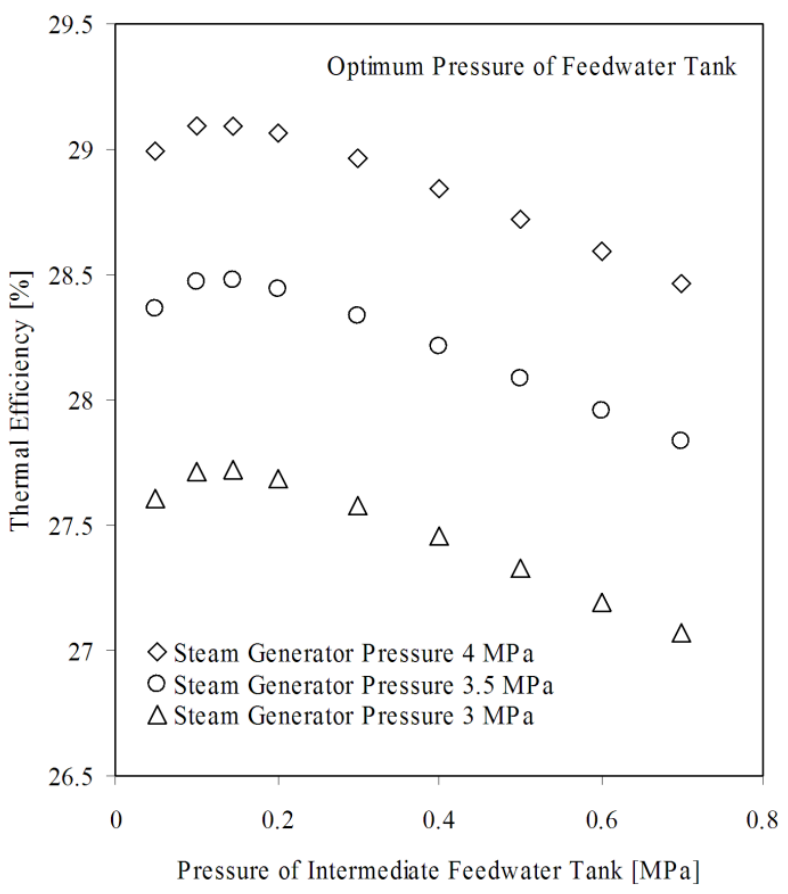

Figure 4. Thermal efficiency versus extraction pressure of turbine for intermediate feed water tank

Figure 6 indicates that the maximum thermal efficiency of regenerative steam cycles is greater than those of basic steam cycle. The value of thermal efficiency is increasing because turbine inlet pressure increases. Thermal efficiency of basic steam cycle without tank was $26.841 \%$ at turbine inlet pressure of $3.5 \mathrm{MPa}$. Thermal efficiencies of regenerative steam cycle with one tank and two tanks were $27.203 \%$ and $27.722 \%$ under turbine inlet pressure of $2.5 \mathrm{MPa}$, respectively. The value of thermal efficiency $(28.475 \%)$ for two tanks on turbine inlet pressure of $3 \mathrm{MPa}$ is higher than thermal efficiency $(28.471 \%)$ for one tank on turbine inlet pressure of $3.5 \mathrm{MPa}$. Feed water tank on $0.8734 \mathrm{MPa}$, the extraction pressure increases because turbine inlet pressure increases while for intermediate feed water tank at $0.1454 \mathrm{MPa}$, the extraction pressure is essentially independent of the turbine inlet pressure. The quantity of steam flowing through the condenser decreases with increasing in the amounts of tanks. Therefore, less heat is vomited to the river water for cooling water of 225.327 liter/s. So that the thermal pollution decreases. The values of steam mass flowrate into the condenser by Cycle-Tempo are 3.231 $\mathrm{kg} / \mathrm{s}$ without tank, $3.142 \mathrm{~kg} / \mathrm{s}$ with one tank (feed water tank), and $3.108 \mathrm{~kg} / \mathrm{s}$ with two tanks (including feed water tank and intermediate feed water tank) under thermodynamic conditions of turbine inlet temperature of $435^{\circ} \mathrm{C}$. 


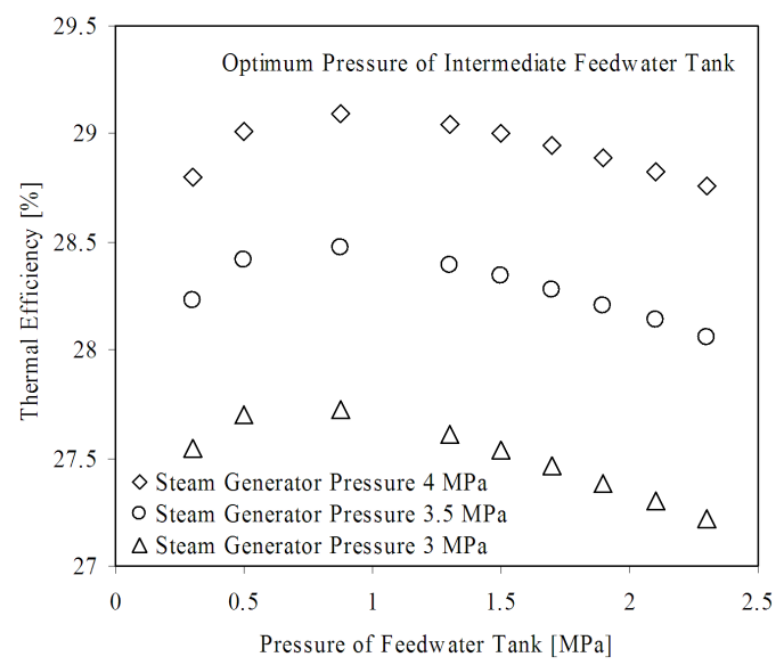

Figure 5. Thermal efficiency versus extraction pressure of turbine for feed water tank

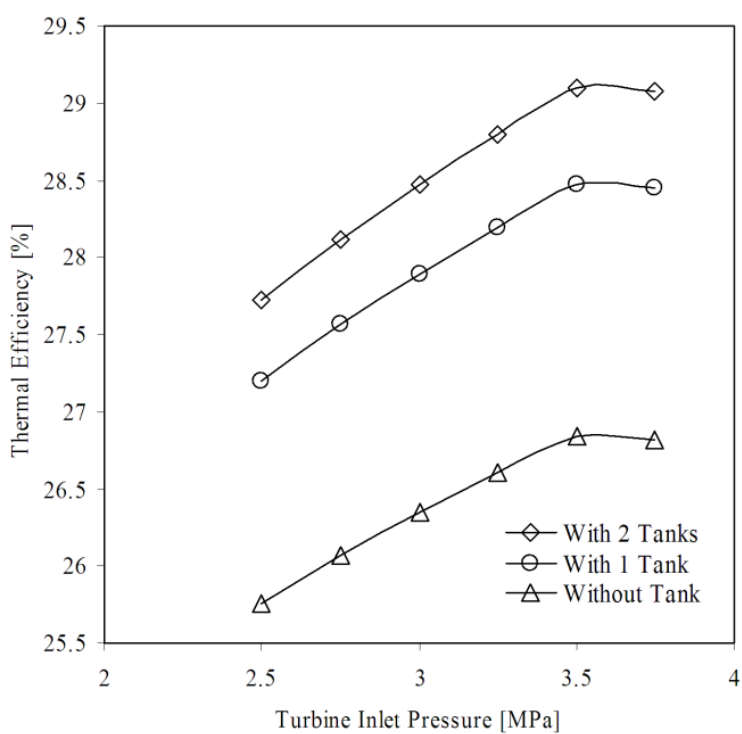

Figure 6. Thermal efficiency against turbine inlet pressure for HTGR-10 concept

Figure 7 shows the thermal efficiency of steam cycles against the amounts of tanks. The thermal efficiency is increasing with the number of tanks and turbine inlet pressure under same temperature $\left(435{ }^{\circ} \mathrm{C}\right)$. The improvement of thermal efficiency decreases with an increase in the amounts of tanks for steam cycle of HTGR-10 with thermal power of $10 \mathrm{MW}_{\text {th. }}$. For regenerative steam cycle with two tanks (including feed water tank and intermediate feed water tank), it was obtained the value of the thermal efficiency of $28.475 \%$ under steam generator pressure of $3.5 \mathrm{MPa}$. For regenerative steam cycle with one tank (feed water tank), it was yielded the value of the thermal efficiency of $28.471 \%$ at steam generator pressure of 40 bars. Therefore, the use of two tanks is better than that of one tank. For the present case, the mechanical power of turbine was approximately $3.534 \mathrm{MW}$ to produce the maximum thermal efficiency of steam cycle of $29.096 \%$ on steam generator pressure of $4 \mathrm{MPa}$, as seen in Figure 7 . The improvement in this thermal efficiency with the various tanks will result in the construction of the HTGR-10 to the electrical power of about $3.075 \mathrm{MW}_{\mathrm{e}}$. This result shows improvement values of as much as $2.65 \%$ in thermal efficiency and $0.271 \mathrm{MW}_{\mathrm{e}}$ in electric power output. Thus this study shows that regenerative steam cycle for HTGR-10 concept is more efficient as compared to basic steam cycle as it preserves the environmental quality.

Table 3 identifies isentropic turbine efficiency for small power reactor with steam cycle including HTR-10, RGTT30 concept, and the present work (HTGR-10 concept) by using the Cycle-Tempo software. Operating conditions of them were conducted with the same data at the reactor core. It can be seen that isentropic turbine 
Jurnal Iptek Nuklir Ganendra

Ganendra Journal of Nuclear Science and Technology

Vol. 20, No. 2, Juli $2017: 73-81$

efficiency of the HTGR-10 concept is higher than those of others. This is caused transmitted heat flow within condenser for the HTGR-10 concept is low so that cooling water is small for the same thermal power. The outlet temperature of the cooling water is $22.01{ }^{\circ} \mathrm{C}$ and mass flow rate is $225.327 \mathrm{~kg} / \mathrm{s}$. This result shows that the regenerative steam cycle with two tanks can be properly applied for the HTGR-10 concept.

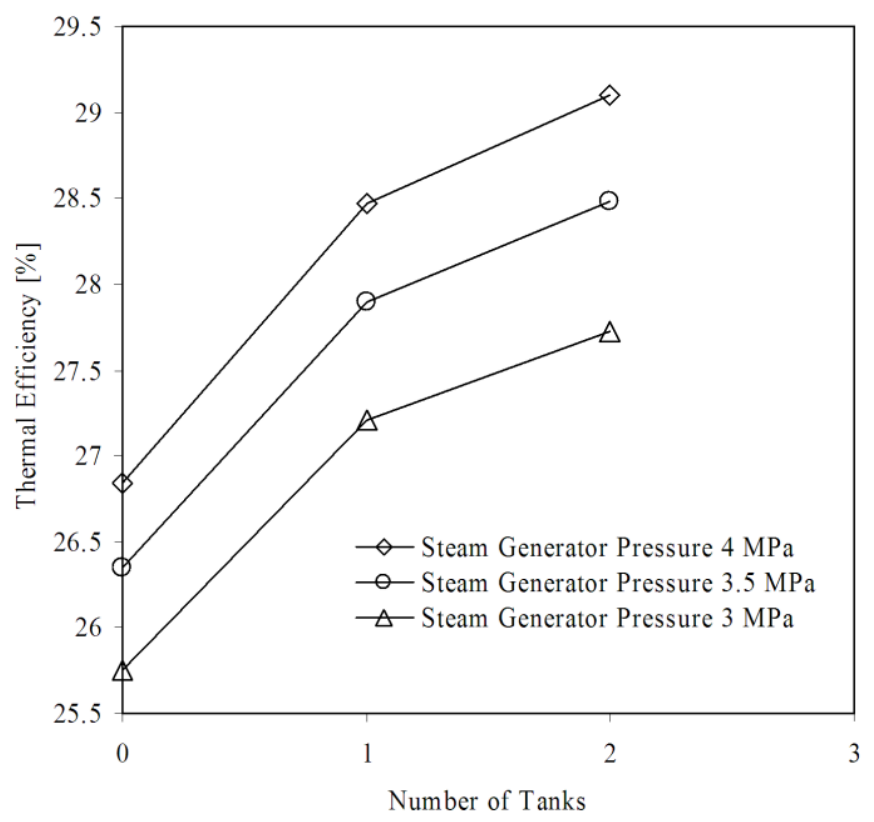

Figure 7. The effect of thermal efficiency on amounts of tanks for HTGR-10

Table 3. Thermodynamic data comparisons of steam turbine cycle.

\begin{tabular}{lccc}
\hline \multicolumn{1}{c}{ Observed Parameter } & HTR-10 [11-15] & RGTT30 [13] & HTGR-10*) \\
\hline Thermal power, $\mathrm{MW}_{\text {th }}$ & 10 & 30 & 10 \\
Electricity power, $\mathrm{MW}_{\mathrm{e}}$ & 2.5 & 7.27 & 3.075 \\
Core inlet temperature, ${ }^{\circ} \mathrm{C}$ & 250 & 250 & 250 \\
Core outlet temperature, ${ }^{\circ} \mathrm{C}$ & 700 & 700 & 700 \\
Turbine inlet temperature, ${ }^{\circ} \mathrm{C}$ & 435 & 435 & 435 \\
Mass flow rate of steam, $\mathrm{kg} / \mathrm{s}$ & 3.47 & 8.691 & 3.918 \\
Turbine efficiency, $\%$ & 87.48 & 88.3 & 89.8 \\
\hline
\end{tabular}

$\left.{ }^{*}\right)$ It was calculated by using Cycle-Tempo simulation software tool.

\section{CONCLUSIONS}

The present study focuses on the electrical power generation based on regenerative steam cycle that can be very useful for HTGR-10 concept with thermal power of $10 \mathrm{MW}_{\text {th. }}$. The analyses of the efect of thermodynamic parameters on the thermal efficiency of the regenerative steam cycle leads to the following points: (a). Thermal efficiency increases with an increase of amounts of tanks (including feed water tank and intermediate feed water tank); (b). There is extraction pressure combination that gives the maximum thermal efficiency of $29.096 \%$; (c). The optimum thermal efficiency should run at an inlet pressure of intermediate feed water tank from $0.05 \mathrm{MPa}$ to $0.7 \mathrm{MPa}$ and an inlet pressure of feed water tank from 0.3 MPa to $2.3 \mathrm{MPa}$; (d). Increased efficiency of the turbine will enhance thermal efficiency; (e). For the condition of the pumps efficiencies remains, the thermal efficiency value rises.

\section{AKNOWLEDGEMENTS}

This work is supported by the Center for Nuclear Reactor Technology and Safety, National Nuclear Energy Agency of Indonesia with project code of SPDIPA080.01.1.450310/2017. 
Thermodynamics Analyses of Regenerative Steam Cycle with Two Tanks for HTGR-10 Concept (Sri Sudadiyo, et all.)

\section{REFERENCES}

[1]A. Zandian and M. Ashjae. "Thermal Efficiency Improvement of a Steam Rankine Cycle by Innovative Design", Renewable Energy, vol. 51, pp. 465-473, 2013.

[2]B. Ghorbani, M. Ghashami, M. Ashjae and H. Hosseinzadegan. "Electricity Production with Low Grade in Thermal Power Plants", Energy Conversion and Management, vol. 94, pp.1-11, 2015.

[3]J.G. Andreasen, U. Larsen, T. Knudsen and F. Haglind. "Design and Optimization of a Novel Rankine Cycle with Improved Boiling Process", Energy, vol. 91, pp. 48-59, 2015.

[4]Y. Cengel and M. Boles. "Thermodynamics, an Engineering Approach", $8^{\text {th }}$ Edition, McGraw-Hill Publishing, 2015.

[5]A.A. Jubori, A. Daabo, R.K. Al-Dadah, S. Mahmoud and A.B. Ennil. "Development of Micro-Scale Axial and Radial Turbines for Low-Temperature Heat Souce Driven Organic Rankine Cycle", Energy Conversion and Management, vol. 130, pp.141-155, 2016

[6]Y. Wang, Y. Niu, X. Zhang, Z. Wang, S. Wang and S. Hui. "Optimization and Energy Integration of Heat Recovery and Power Generation System”, Applied Thermal Engineering, vol. 107, pp. 294-300, 2016.

[7]A. Alkhedhair, Z. Guan, I. Jahn, H. Gurgenci and S. He. "Water Spray for Pre-Cooling of Inlet Air for Natural Draft Dry Cooling Towers", International Journal of Thermal Sciences, vol. 90, pp. 70-78, 2015.

[8]F. Niu, L. Tian, Y. Yu, R. Li, L. Timothy and Norman. "Studies on Flow Instability of Helical Tube Steam Generator", Nuclear Engineering and Design" vol. 266, pp. 63-69, 2014.

[9]W. Shao, Z. Cui and L. Cheng. "Multi-Objective Optimization Design of Air Distribution of Grate Cooler by Entropy Generation Minimization and Generic Algorithm", Applied Thermal Engineering, vol.108, pp. 76-83, 2016.

[10] M. Liu, T. Woudstra, E.J. Promes, S.Y. Restrepo and P.V. Aravind. "System Development and SelfSustainability Analysis for Upgrading Power", Energy, vol. 68, pp. 377-384, 2014.

[11] M.J. Wang, J.J. Peir, R.J. Sheu and J.H. Liang. "Effects of Geometry Homogenization on the HTR-10 Criticality Calculations", Nuclear Engineering and Design, vol. 271, pp. 356-360, 2014.

[12] M. Hiruta, G. Johnson, M. Rostamian, G.P. Potirniche, A.M. Ougouag, M. Bertino, L. Franzel and A.. Tokuhiro. "Computational and Experimental Prediction of Dust Production in Pebble Bed Reactors", Nuclear Engineering and Design, vo. 263, pp. 509-514, 2013.

[13] S. Sudadiyo and J.S. Pane. "Desain Awal Turbin Uap Tipe Aksial Untuk Konsep RGTT30 Berpendingin Helium”, Jurnal Tri Dasa Mega, vol.18, pp. 65-74, 2016.

[14] L. Peng, C. Zhipeng, Z. Yanhua, S. Jun, C. Fubing, S. Lei, L. Fu, D. Yujie and Z. Zuoyi. "Study on Air Ingress of the $200 \mathrm{MW}_{\mathrm{e}}$ Pebble-Bed Modular High Temperature Gas-Cooled Reactor", Annals of Nuclear Energy, vol. 98, pp. 120-131, 2016.

[15] M. Hafid and M. Lacroix. "An Inverse Heat Transfer Method for Predicting the Thermal Characteristics of a Molten Material Reactor", Applied Thermal Engineering, vo.108, pp.140-149, 2016. 